\title{
PSYCHOSOCIAL INFLUENCES ON FIRST-YEAR INTERNATIONAL STUDENTS LEARNING OUTCOMES IN CHINESE UNIVERSITIES
}

\author{
Xinchao Li \\ Teaching Affairs Office-Jiangsu University, 301 Xuefu Rd, Jingkou District, Zhenjiang, Jiangsu, China \\ Isaac Kwaku Asante \\ School of Teacher Education-Jiangsu University, 301 Xuefu Rd, Jingkou District, Zhenjiang, Jiangsu, China
}

Article DOI: $\underline{\text { https://doi.org/10.36713/epra6170 }}$

\begin{abstract}
-
This study examined the psychosocial state of international students and the resultant effect on the students' first-year learning outcome. Of interest was whether participants first-year experiences would influence learning. We grounded this study on student involvement and psychosocial theories. A total of 600 international students from 83 Chinese Universities participated in an online survey. The psychosocial factors were measured with both the First Year University Experience Questionnaire and 12-point GHQ questionnaires and analysed with hierarchical multiple regression. The result was statistically significant explaining 24\%, 27\% and 33\% variance on international students' learning outcomes, after controlling for all the psychosocial factors. Moreover, the results suggested the need for University administrators to provide counselling support and promote sustainable psychosocial oriented programs.
\end{abstract}

KEYWORDS: First-year experiences, international students, learning outcomes, psychosocial influence

\section{INTRODUCTION}

Globalization provides opportunity for people to move from one country to another in pursuit of international education. The number of international students moving to Asia to study is increasing on a yearly basis. In 2018-19 academic year, 492,185 international students were admitted in Chinese Universities and programs (The Ministry Of Education, 2019). Even though, these admitted students have had universities experience in their home country, they still show signs of maladjustment to their new university. Further, they exhibit negative adjustment characteristics like loneliness, stress and depression (Smith \& Khawaja, 2011; Spencer-Oatey, Dauber, Jing, \& Lifei, 2017). In fact, these types of psychosocial problems are very critical, if not checked can degenerate into sever forms thereby affecting the students' total adjustment in the new environment. Because recent studies have identified the interconnection between international students' adjustment and other outcomes including suicidal ideation, learning outcomes and academic integration (Han, Pistole, \& Caldwell, 2017; Karaman, \& Watson, 2017; Lowinger et al., 2016).

In adjusting to Chinese university environment, two classes of international students emerge. The categorization of international students is based on their period of adjustment. Some acclimatized quickly whereas others take a long time to adjust to the university community. The "slow adjusters" begin to develop symptoms of anxiety and depression due to homesickness. The highly depressed international students find it difficult to socially integrate in their respective universities. Therefore, an increase in their social exclusion make them lonely.

The present study acknowledges that each foreign student has unique educational experiences that affect their learning. These unique experiences inform the analysis of the extent psychosocial factors like depression, anxiety, and loneliness (Brunsting, Zachry, \& Takeuchi, 2018a; Rajkumar, Sooraj, Sandeep, \& Harish, 2015) influences the learning outcomes of international students 


\section{LITERATURE REVIEW}

The concept of this study utilised past literature and psychosocial theories. According to Rodgers (1980), psychosocial theories incorporate emotions, actions and thought to create a rich and unique image of life. Again, those psychosocial theories examine students' concerns, changes in thought, emotions, behaviour, appreciation, and relationships at college (Chickering \& Reisser, 1993). The key theories underpinning this study are Wcurve and Student involvement theories.

The w-curve theory claim that first-year international students undergo several stages of mental and emotional adjustment in their transition process in the host country (Gullahorn \& Gullahorn, 1962). Accordingly, Zeller and Mosier (1993) identified five distinct phases students go through in adapting to college life. Kunuroglu, van de Vijver, and Yagmur (2016) posits that the w-curve shows a psychological pattern first year college students experience. The next theory, student involvement theory emphasis the magnitude and value of students' emotional and physical energy in their university experience (Astin, 1984). Further, the student involvement theory claims students' college experiences are positively related to their learning and individual advancement. Moreover, a typically uninvolved student disregards study, spends little time on campus and avoid social activities (Astin, 1984). These two theories support the claim that psychological and social environment have effect on first-year international students' academic experience. For example, previous studies identify emotional and environmental factors key determinants that influence first year students learning outcomes (Alexander C. McCormick, Jillian Kinzie, 2013; Pace, 1980; Salami, 2011; Tom, 2015).

In addition, Betancourt, Speelman, Onyango, and Bolton (2009) claim young adults are prone to anxiety, depression, and prolonged psychosis. And if not checked will lead into psychosocial disorders and negative characteristics such as maladjustment, poor interpersonal relationships, weak social connections, and social malfunction in the host country (Gilborn et al. 2006). Smith, Grealish, and Henderson, (2018) posits that the complexity of first year international students lifestyle with associated psychosocial problems affect their ability to learn. Also. Gruber, Fub, Voss, and Glaser-Zikuda (2010) recognize that psychological factors influence the sense of satisfaction of students within the college. Because most international students moving to a new country might be the first time they stayed outside of their family, therefore struggle with adjustment in the new environment.

\section{Learning Outcomes}

Even though the purpose of learning outcomes cannot be underestimated in this study, the international students' psychosocial state is paramount. Because learning outcome is either perceived as a mechanism for educational and instructional planning or as a measure of effectiveness and accountability (Prøitz, 2010). According to Entwistle (2005) most educationalist define learning outcome as a measure of students' ability to complete a course of study or achieve a grade and finally the type of degree awarded to them. And yet Astin (1984) recognize learning outcome as a function of the students' profound engagement in the study environment the university present. A recent report on "Trends in the first year experience in Australian universities" (2000) stated that "social nature of the university experience has the potential of making a positive impact on academic performance, and influence the individual's sense of competence" (Krause, Hartley, James, \& Mcinnis, 2005)

Again, Rychen (2004) identify two broad forms of learning outcomes- cognitive and non-cognitive outcomes. Shavelson and Huang (2003) elucidated cognitive learning outcomes as a product which span from specific to global knowledge domains and/or problem-solving ability. Moreover, non-cognitive learning outcomes involves changes in the development of certain beliefs, intercultural competence and ability to successfully live in a different society without difficulties (Nusche, 2018)

\section{Depression}

\section{PSYCHOSOCIAL FACTORS}

In 2017, the WHO described depression as mental sickness, prolonged sadness, avoidance, guilt feeling, insomnia, and low concentration (World Health Organization, 2017). Basically, depression is among the common psychological factors that affect new students (Verschuur, Eurelings-Bontekoe, \& Spinhoven, 2004). For example, a study by Smith and Khawaja (2011) found that among all the psychological symptoms university counsellors received depression ranked high on the list. Furthermore, high depression symptoms among international students destabilized their cognition, mood, and motivation (Böker \& Northoff, 2018).

Anxiety

Anxiety is another psychosocial factor international students endure during transition. Moller, Roth, Niemiec, Kanat-Maymon, and Deci (2018) identify that students with intense anxiety worry about desertion, feel rejected and find it difficult to open up or rely on others. As a result, according to Khawaja and Duncanson (2008), such students will not discuss with their lecturers, parents and/or mental health professionals about their problems. They will rather respond negatively through avoidance of studies, having poor academic performance, and other psychological conditions. Hechanova-Alampay, Beehr, Christiansen, and Van Horn (2002) also consented that foreign students hardly overcome severe anxiety and frustrations. According to a recent study on 
stress and academic performance as well as testing (Espín, Marquina, Hidalgo, Salvador, \& Gómez-Amor, 2016; Gagnon \& Wagner, 2016; Zandara et al., 2016) an acute stress or anxiety influence academic performance before and/or during testing. Hence, when anxiety sensations are controlled before a test can help counter negative effects of anxiety on performance. Therefore, it assist test-anxious students to perform better even under pressure (Ramirez \& Beilock, 2011).

\section{Loneliness}

Loneliness is the personal feeling of lack of intimated social connection with other people within a given society. It stems from the imbalances among ones desired and social relationship leading to emotional distress (Cacioppo \& Cacioppo, 2018). Loneliness is a general problem which affects everybody regardless of gender, race, age, and culture (Fried et al., 2020). Most international students experience some level of isolation in any stage of their transitions. Because most of them feel distant from their friends and relatives in their native country, which lead them to keep to themselves and feel lonely (Kim, Collins, Rennick, \& Edens, 2017). Studies have shown that cultural, educational, language or social disparities intensify loneliness, marginalization and explicit or implicit exclusion (Trice, 2003; Wang, 2018).

Because the needs of international students far outstripped assistance Chinese universities staff could provide, a research is needed to identify the psychological needs of international students (typically first-year international students) in their transition and adjustment. Nelson (2019) posits that the key determinants for new college students to adjust and settle well for studies are the level of assistance and resources they can access. Consequently, in most higher institutions because of the pressure placed on them to provide data on the quality of teaching and learning, they show little interest in their students' attitudes and values as well as their emotional health. Rather, focus on meeting the external universities rating institutions' requirements covering inputs, activities and scientific reports. These indices do not indicate how much effort university authorities put in solving problems relating to their students' mental health (Nusche, 2018), hence encouraging them to ignore mediation measures.

Although several studies have been conducted on psychosocial influences on international students' academic performance in USA and Europe (Brunsting, Zachry, \& Takeuchi, 2018b; Fong et al., 2017; Hoti, Heinzmann, Müller, \& Buholzer, 2017; Huhn et al., 2017; Witkowska, Witkowski, \& Goczek, 2018), to date it is rarely seen in Chinese literature the association among psychosocial factors (e.g. depression, anxiety and loneliness) and learning outcomes on first-year international students. For this reason, the aim of this study on international students was to examine the impact of psychosocial factors on learning outcomes during the first year of international students after moving to China. With the two theories and the current literature, this study expects that lowering the effect of psychosocial factors (such as anxiety, depression and loneliness) will increase the international students' involvement and performance. To achieve the objectives of this study, we used crosssectional study method and hierarchical multiple regression to investigate the effect of psychosocial factors on international students learning outcome and transition. The method used was statistically successful.

\section{Participants}

\section{METHODS}

In this cross-sectional study, participants were selected through convenience sampling method. The convenience sampling method was appropriate for this study because of how scattered the participants were considering the size of China as a country and the number of universities. The data were collected from 600 first-year international students studying in 83 Chinese Universities. Out of 492,185 international students in China, only 600 participated in the survey. Out of the 600 participants $393(65.5 \%)$ participants were males and $207(34.5 \%)$. were females. The participants age ranged from 21-40 years old with a mean $2.34(S D=1.171)$. The degree level of the participants was $20.7 \%$ for doctoral students, $30.8 \%$ for master students, $38.5 \%$ for bachelor students and $10.0 \%$ for associate degree students. Again, the majority of the participants live in an oncampus apartment $(\mathrm{N}=417,69.5 \%)$, those in private and at home residence were $21.0 \%$ and $9.5 \%$ respectively. Approximately 73.7 of the respondents' study in the English language with 26.3 studying in the Chinese language. Majority of the participants were from Asia and Africa and their length of stay in China ranges from just a semester to within a year. Approximately 41 percent reported a one year stay in their Universities (See Table 1) 


\begin{tabular}{|c|c|c|c|}
\hline Table $1 \mathrm{De}$ & aphics of Participants & $f$ & $\%$ \\
\hline Gender & Male & 393 & 65.5 \\
\hline & Female & 207 & 34.5 \\
\hline Age & Under 21 & 170 & 28.3 \\
\hline & $21-25$ & 190 & 31.7 \\
\hline & $26-30$ & 146 & 24.3 \\
\hline & $31-36$ & 63 & 10.5 \\
\hline & $36-40$ & 25 & 4.2 \\
\hline & $40+$ & 6 & 1.0 \\
\hline Nationality & Africa & 219 & 36.5 \\
\hline & Asia & 318 & 53.0 \\
\hline & Eastern Europe & 55 & 9.2 \\
\hline & Americas & 8 & 1.3 \\
\hline Degree & $\mathrm{PhD}$ & 124 & 20.7 \\
\hline & Masters & 185 & 30.8 \\
\hline & Bachelor & 231 & 38.5 \\
\hline & Associate Degree & 60 & 10.0 \\
\hline Length of stay & Just a semester & 123 & 20.5 \\
\hline & Just one year & 176 & 29.3 \\
\hline & Within a semester & 56 & 9.3 \\
\hline & Within one year & 245 & 40.8 \\
\hline
\end{tabular}

\section{Procedure}

International students from Chinese Universities within their first year of study volunteered to take part in an online survey. The data were collected within the first year of their stay in China, because by then those international students have had a certain amount of international experience. The survey was designed in esurveycreator.com and circulated through WeChat link. The survey was open for four months from December to March of 2018-2019 academic year. The sample covered both the Chinese Language program and regular (Undergraduate, Masters and $\mathrm{PhD}$ ) international students.

Out of 900 students who received the survey, only 600 students completed the entire questionnaire. The completed questionnaires were quite small compared to the number of international students studying in China. Even though the number of completed questionnaires received were inadequate, it was sufficient for this study.

\section{MEASURES}

The 12-items General Health Questionnaires (Lundin, Hallgren, Theobald, Hellgren, \& Torgén, 2016) and the Higher Education Academy First-Year Experience (Yorke \& Longden, 2008) were materials used to collect the data. A recent validity and reliability test on both Higher Education Academy First-year Experience and General Health Questionnaires in higher education (Yorke \& Longden, 2008) and clinics (Kashyap \& Singh, 2017; Lundin et al., 2016; Rajkumar et al., 2015) were statistically significant. The Cronbach Alpha for this study was 0.87 for all the constructs.

Anxiety: General Health Questionnaires (GHQ) (Lundin et al., 2016) was employed to evaluate anxiety level of international students in their first year of study. Three questions were adapted from the 12 -items GHQ included (1) I always feel am under pressure, (2) I often lost a lot of sleep because of fear and (3) I am not encouraged as I should be for my studies. The respondents' anxiety levels were appraised using Likert scale. The Cronbach's alpha for the anxiety construct was 0.72 .

Depression: Two questions from the survey were used to evaluate the depression among international students. The questions were adapted from the 12-items GHQ. The 5-point scale was used to rate the two questions included (1) I am sometimes unhappy and depressed and (2) At times I feel I cannot overcome my difficulties. The Cronbach's alpha for the depression construct was 0.72 .

Loneliness. Three questions used in evaluating the participants' state of loneliness were from the Higher Education Academy First-Year Experience Survey. They were ranked on a 5-point scale with one indicating strongly disagree and five for strongly agree. The questions adapted from the survey were; (1) I have a habit of keeping myself out of the public (2) I do not feel I belong to any academic grouping within this institution and 
(3) I am not personally interested in this university's extracurricular activities. The loneliness construct had a Cronbach's Alpha of 0.70

Dependent variable: One item from the questionnaire administered was used as our outcome variable. The participants were asked a question "Did your first-year experience affect your GPA?". We gave the participants the option to choose from Strongly Agree to Strongly Disagree. Their responses were tested against all the independent variables using hierarchical multiple regression.

\section{ANALYSIS}

First, the demographics of participants were computed. Afterwards, we examined our model by conducting a hierarchical multiple regression among all the variables using the software SPSS v.22.0 (IBM Corporation, 2013). In conducting hierarchical multiple regression analysis for the dependent variable, we tested for the normality assumption in regression. The skewness and kurtosis in the residual were -0.21 and -1.09 respectively. The outcome of the test met the normality assumption for multivariate regression of -1.96 to 1.96 (Doane \& Seward, 2011).

\section{RESULTS}

The results of this study ensured the assumptions of linearity, normality, and homoscedasticity were strictly followed. Again, the correlations amongst the independent variables (anxiety, depression and loneliness) in this study were evaluated as presented in Table 2 . The correlations were very weak to moderate, ranging from $r=-.12, p<.037$ and $r=.21, p<.000$. This results show that multicollinearity was met. Most of the independent variables statistically correlated with each other which supported that the data was good fit to correlate with the dependent variable. Table 2 displays the unstandardized regression coefficients $(B)$, intercept, and standardized regression coefficients $(\beta)$ for each variable.

In the first step in this analysis, three questions under the anxiety predictor were entered: (1) I always feel am under pressure, (2) I often lose a lot of sleep because of fear and (3) I am not encouraged as I should be for my studies. This model was statistically significant $F_{(12,170)}=12.17, p<.000$ and explained $24 \%$ of variance in the effects on learning outcome. All three anxiety questions contributed significantly to the model. After entry of depression questions at Step 2 the total variance explained by the model was $26.7 \%$ with $F_{(9,129)}=4.36, p$ $<.000$. The introduction of loneliness questions explained additional $6.2 \%$ of variance in the effect on learning outcomes, after controlling for all the independent variables $\left(\Delta R^{2}=.108 ; F_{(8,942)}=8.086, p<.000\right)$. Finally, in adjusted model, five out of eight questions under predictor variables were statistically significant, with one question under loneliness predictor recording Beta value $(\beta=.21, p<.000)$ than the rest of the predictors.

Table 2 Hierarchical Multiple Regression Analyses Predicting Psychosocial influence on International Students in China

\begin{tabular}{|c|c|c|c|c|c|c|c|c|c|}
\hline Model & $\boldsymbol{R}$ & $\boldsymbol{R}^{2}$ & $\Delta R^{2}$ & $\Delta F$ & $\boldsymbol{B}$ & $S E$ & $\boldsymbol{\beta}$ & $t$ & Sig. \\
\hline Step 1 & .24 & .058 & .058 & 12.17 & & & & & \\
\hline I always feel am under pressure & & & & & .20 & .07 & .15 & 3.01 & .003 \\
\hline $\begin{array}{l}\text { I often lose a lot of sleep because } \\
\text { of fear }\end{array}$ & & & & & .23 & .07 & .15 & 3.05 & .002 \\
\hline $\begin{array}{l}\text { I am not encouraged as I should } \\
\text { be for my studies }\end{array}$ & & & & & -.15 & .06 & -.11 & -2.54 & .011 \\
\hline Step 2 & .27 & .071 & .014 & 4.36 & & & & & \\
\hline I always feel am under pressure & & & & & .26 & .07 & .19 & 3.62 & .000 \\
\hline $\begin{array}{l}\text { I often lose a lot of sleep because } \\
\text { of fear }\end{array}$ & & & & & .31 & .08 & .21 & 3.90 & .000 \\
\hline $\begin{array}{l}\text { I am not encourage as i should } \\
\text { be for my studies }\end{array}$ & & & & & -.09 & .07 & -.06 & -1.33 & .184 \\
\hline $\begin{array}{l}\text { I am sometimes unhappy and } \\
\text { depressed }\end{array}$ & & & & & -.15 & .08 & -.11 & -2.04 & .042 \\
\hline $\begin{array}{l}\text { At times I felt I cannot overcome } \\
\text { my difficulties }\end{array}$ & & & & & -.12 & .08 & -.08 & -1.49 & .137 \\
\hline Step 3 & .33 & .11 & .04 & 8.09 & & & & & \\
\hline I always feel am under pressure & & & & & .26 & .07 & .19 & 3.675 & .000 \\
\hline
\end{tabular}


I often lose a lot of sleep because

of fear

I am not encouraged as I should

be for my studies

I am sometimes unhappy and

depressed

At times I felt I cannot overcome

my difficulties

I have a habit of keeping myself

out of the public

I do not feel I belong to any

academic grouping within this

institution

I am not personally interested in

this university's extracurricular

activities

$\begin{array}{lllll}.22 & .08 & .15 & 2.628 & .009 \\ -.14 & .06 & -.10 & -2.05 & .041 \\ -.15 & .07 & -.11 & -2.12 & .034 \\ -.17 & .08 & -.12 & -2.09 & .037 \\ -.05 & .07 & .05 & .93 & .355 \\ .27 & .07 & -.04 & -.71 & .478 \\ & & & & \\ .06 & .06 & .21 & 4.50 & .000\end{array}$

\section{DISCUSSION}

Within the psychosocial theories as a framework (Astin, 1984; Gullahorn \& Gullahorn, 1962), this present study investigated how psychosocial factors influence international students' learning outcomes. Anxiety, depression and loneliness were predictors identified in the literature as good candidates for influencing international students transition and learning outcomes. The general and individual effects on learning outcomes were analysed. Almost all the measures of psychosocial factors significantly correlated with the dependent variable of learning outcomes.

The findings from this study suggest that psychosocial factors are of genuine concern to international students. Anxiety, depression and loneliness consequently influence first-year international students learning in the university. The findings replicate results from past studies examining psychosocial factors with academic performance. For example Ahmed (2018) proved that International students perceived to have severe anxiety and depression demonstrated weak academic achievement. Anxiety explained one fourth of the total variance on learning outcomes. Again, the robust relationships among the variables suggests that the results were not simply the findings of a methodological relic. Further, the current findings show that a higher degree of psychosocial factors predicted declines in international students learning outcomes. The effects of international student's psychosocial status were obvious, going beyond poor transition to predict decrements in learning outcomes overtime.

Given the effect of psychosocial factors on learning outcomes, researchers should investigate how anxiety, depression and loneliness influences international students learning outcomes. Therefore, this study makes an important contribution through the model that was tested, which suggested ways first-year international students experiences can affect learning outcomes. The hierarchical multiple regression analysis indicated that psychosocial factors of first-year international students have an inverse relationship with learning outcomes. These findings highlighted the relationship among different factors that affect international students in their first year.

Our results underline the need to identify and provide support for international students who have social and emotional difficulties on the university campus. Our measures of psychosocial factors suggest that international student affairs department in Chinese universities have a role to play, as they appear to have background information on first-year international students. Raymond (2018) asserted that most international students are troubled and unhappy in the new environment and their future. Our results also suggest an immediate intervention may yield many benefits leading to an increased psychological and social well-being, improved learning and cultural adjustment.

This study contributes to existing literature on transition and adjustment among international students. Accordingly, this study is among the first ones to examine the effects of psychosocial factors on first-year international students learning outcomes in China. And this study may be a good candidate for the development of pro-international students' psychosocial programs to facilitate adjustment in China. Next, as this study is a psychosocial-oriented study, it highlighted some empirical suggestion that could back the planning of psychosocial- oriented programs. Lastly, this study reinforced the results of past studies, for instance, those of Sullivan \& Kashubeck-West (2015); Szabo, Ward, \& Jose (2016).

Although the findings of this study suggested that psychosocial factors have an influence on international students' transition, the results need to be accepted with care. The first limitation in this study relates to the 
sample size, which was small compared to the total population of international students in China. Though the current findings were based on a relatively small sample, the findings need to be applied in a large international student body to understand the extent to which psychosocial factors may affect international students learning. Again, even though the anonymity of participants were assured in the collection of data, the self-report survey employ may relate to a bias response. The findings of this study suggest that future research may expand on the results and the theoretical concepts espoused in this study and relate it to the psychosocial disposition of Chinese students in hosting international students at their universities. Further, to replicate our results future research may not only use similar cross-section designs, but also longitudinal and diary studies.

\section{CONCLUSION}

As predicted, minimizing psychosocial factors create sound emotional and social experiences for international students in the adjustment process. Additionally, we found that the psychosocial measures had significant influence on transition experience of first-year international students, which later predicted a decreased learning outcome. Our findings supported the theories used in this paper, particularly on international students' experience in the first year of their study. Finally, we admit that the objectives set for ourselves were met and we have statistically proved the psychosocial factors influence on learning outcomes among international students.

\section{REFERENCES}

1. Ahmed, O. (2018). Relationship Between Loneliness and Mental Health Among First- Year Undergraduate Students: Mediating Role of Timeline Browsing and Chatting on Facebook. International Journal of Contemporary Education, 1(2), 86. https://doi.org/10.11114/ijce.vli2.3625

2. Alexander C. McCormick, Jillian Kinzie, and R. M. G. (2013). Student engagement: Bridging research and practice to improve the quality of undergraduate education. In Higher education: Handbook of theory and research (vol. 28, pp. 47-92). Dordrecht: The Netherlands: Springer. https://doi.org/10.1007/978-94-007-5836-0

3. Astin, A. W. (1984). Student Involvement : A Developmental Theory for Higher Education, (July), 518-529.

4. Betancourt, T. S., Speelman, L., Onyango, G., \& Bolton, P. (2009). A qualitative study of mental health problems among children displaced by war in northern Uganda. Transcultural Psychiatry, 46(2), 238-256.

5. Böker, H., \& Northoff, G. (2018). Depressive syndromes. In Neuropsychodynamic Psychiatry (pp. 219-272). Springer.

6. Brunsting, N. C., Zachry, C., \& Takeuchi, R. (2018a). Predictors of undergraduate international student psychosocial adjustment to US universities: A systematic review from 2009-2018. International Journal of Intercultural Relations, 66, 22-33.

7. Brunsting, N. C., Zachry, C., \& Takeuchi, R. (2018b). Predictors of undergraduate international student psychosocial adjustment to US universities: A systematic review from 2009-2018. International Journal of Intercultural Relations, 66(June), 22-33. https://doi.org/10.1016/j.ijintrel.2018.06.002

8. Cacioppo, J. T., \& Cacioppo, S. (2018). The growing problem of loneliness. The Lancet, 391(10119), 426.

9. Chickering, A. W., \& Reisser, L. (1993). Education and Identity. The Jossey-Bass Higher and Adult Education Series. ERIC.

10. Corporation, I. (2013). IBM SPSS Statistics for Windows. Armonk, NY: IBM Corp.

11. Doane, D. P., \& Seward, L. E. (2011). Measuring skewness: a forgotten statistic? Journal of Statistics Education, 19(2).

12. Entwistle, $N$. (2005). Learning outcomes and ways of thinking across contrasting disciplines and settings in higher education. Curriculum Journal, 16(1), 67-82.

13. Espín, L., Marquina, M., Hidalgo, V., Salvador, A., \& Gómez-Amor, J. (2016). No effects of psychosocial stress on memory retrieval in non-treated young students with Generalized Social Phobia. Psychoneuroendocrinology, 73, $51-62$.

14. Fong, C. J., Davis, C. W., Kim, Y., Kim, Y. W., Marriott, L., \& Kim, S. (2017). Psychosocial factors and community college student success: A meta-analytic investigation. Review of Educational Research, 87(2), 388-424.

15. Fried, L., Prohaska, T., Burholt, V., Burns, A., Golden, J., Hawkley, L., ... O'Sullivan, R. (2020). A unified approach to loneliness.

16. Gagnon, S. A., \& Wagner, A. D. (2016). Acute stress and episodic memory retrieval : neurobiological mechanisms and behavioral consequences, (2), 55-75. https://doi.org/10.1111/nyas.12996

17. Gilborn, L., Apicella, L., Brakarsh, J., Dube, L., Jemison, K., Kluckow, M., ... Snider, L. (n.d.). Orphans and Vulnerable Youth in Bulawayo, Zimbabwe: An Exploratory Study of Psychosocial Well-being and Psychosocial Support Programs.

18. Gruber, T., Fub, S., Voss, R., Glaser-Zikuda, M. (2010). Examining student satisfaction with higher education services. International Journal of Public Sector Management, 23(2), 105-123.

19. Gullahorn, J. T., \& Gullahorn, J. E. (1962). An Extension of the U-Curve Hypothesis ', (1955), 33-47.

20. Han, S., Pistole, M. C., \& Caldwell, J. M. (2017). Acculturative stress, parental and professor attachment, and college adjustment in Asian international students. Journal of Multicultural Counseling and Development, 45(2), $111-126$.

21. Hechanova-Alampay, R., Beehr, T. A., Christiansen, N. D., \& Van Horn, R. K. (2002). Adjustment and strain 
among domestic and international student sojourners: A longitudinal study. School Psychology International, 23(458-474).

22. Hoti, A. H., Heinzmann, S., Müller, M., \& Buholzer, A. (2017). Psychosocial adaptation and school success of Italian, Portuguese and Albanian students in Switzerland: Disentangling migration background, acculturation and the school context. Journal of International Migration and Integration, 18(1), 85-106.

23. Huhn, D., Lauter, J., Ely, D. R., Koch, E., Möltner, A., Herzog, W., ... Nikendei, C. (2017). Performance of international medical students in psychosocial medicine. BMC Medical Education, 17(1), 111.

24. Karaman, M. A., \& Watson, J. C. (2017). Examining associations among achievement motivation, locus of control, academic stress, and life satisfaction: A comparison of US and international undergraduate students. Personality and Individual Differences, 111, 106-110.

25. Kashyap, G. C., \& Singh, S. K. (2017). Reliability and validity of general health questionnaire (GHQ-12) for male tannery workers: a study carried out in Kanpur, India. BMC Psychiatry, 17(1), 102.

26. Khawaja, N. G., \& Duncanson, K. (2008). Using the university student depression inventory to investigate the effect of demographic variables on Students' depression. Journal of Psychologists and Counsellors in Schools, $18(2), 195-209$.

27. Kim, Y. K., Collins, C. S., Rennick, L. A., \& Edens, D. (2017). College experiences and outcomes among international undergraduate students at research universities in the United States: A comparison to their domestic peers. Journal of International Students, 7(2), 395-420.

28. Krause, K.-L., Hartley, R., James, R., \& Mcinnis, C. (2005). the First Year Experience in Australian Universities: Findings From a Decade of National Studies a Project Funded By the Higher Education Innovation Programme Department of Education, Science and Training, (January).

29. Kunuroglu, F., van de Vijver, F., \& Yagmur, K. (2016). Return migration. Online Readings in Psychology and Culture, $8(2), 1$.

30. Lowinger, R. J., Kuo, B. C. H., Song, H.-A., Mahadevan, L., Kim, E., Liao, K. Y.-H., .. Han, S. (2016). Predictors of academic procrastination in Asian international college students. Journal of Student Affairs Research and Practice, 53(1), 90-104.

31. Lundin, A., Hallgren, M., Theobald, H., Hellgren, C., \& Torgén, M. (2016). Validity of the 12-item version of the General Health Questionnaire in detecting depression in the general population. Public Health, 136, 66-74.

32. Moller, A. C., Roth, G., Niemiec, C. P., Kanat-Maymon, Y., \& Deci, E. L. (2018). Mediators of the associations between parents' conditional regard and the quality of their adult-children's peer-relationships. Motivation and Emotion, 1-17.

33. Nelson, M. A. (2019). First-year Students' Reasons for Withdrawing from College. Walden University.

34. Nusche, D. (2018). Assessment of Learning Outcomes in Higher Education, (15). https://doi.org/10.1007/978-3319-74338-7

35. Pace, C. R. (1980). Measuring the quality of student effort. Current Issues in Higher Education, 2, 10-16.

36. Prøitz, T. S. (2010). Learning outcomes: What are they? Who defines them? When and where are they defined? Educational Assessment, Evaluation and Accountability, 22(2), 119-137. https://doi.org/10.1007/s11092-0109097-8

37. Rajkumar, E., Sooraj, K. V, Sandeep, B. H., \& Harish, C. (2015). Psychosocial Problems among Students of Central University of Karnataka : A Comparative Study, 3(9), 44-47. https://doi.org/10.17354/ijss/2015/552

38. Ramirez, G., \& Beilock, S. L. (2011). Writing about testing worries boosts exam performance in the classroom. Science, 331(6014), 211-213.

39. Raymond, K. P. (2018). Mindfulness, Self-Compassion and Threat Related Attentional Bias: Implications for Social Anxiety and Loneliness in Late Adolescent College Students. ProQuest Dissertations and Theses, (May), 209.

Retrieved

from http://ezphost.dur.ac.uk/login?url=https://search.proquest.com/docview/2065125958?accountid=14533\%0Ahttp:/ lopenurl.ac.uk/ukfed:dur.ac.uk? genre=dissertations $+\% 26+$ theses \&issn=\&title=Mindfulness $\% 2 C+$ SelfCompassion+and +Threat+Related+Attentional+Bias\%3A+Impli

40. Rodgers, R. F. (1980). Theories underlying student development. Student Development in Higher Education: Theories, Practices, and Future Directions, 27.

41. Rychen, D. S. (2004). Key competencies for all: an overarching conceptual frame of reference. Developing Key Competencies in Education: Some Lessons from International and National Experience. Geneva: UNESCO/International Bureau of Education.

42. Salami, S. O. (2011). Psychosocial Predictors of Adjustment among First Year College of Education Students. Online Submission, 8(2), 239-248.

43. Shavelson, R. J., \& Huang, L. (2003). Responding responsibly. Change: The Magazine of Higher Learning, 35(1), $10-19$.

44. Smith, M. R., Grealish, L., \& Henderson, S. (2018). Shaping a valued learning journey: Student satisfaction with learning in undergraduate nursing programs, a grounded theory study. Nurse Education Today, 64, 175-179. https://doi.org/10.1016/j.nedt.2018.02.020

45. Smith, R. A., \& Khawaja, N. G. (2011). A review of the acculturation experiences of international students International Journal of Intercultural Relations, 35(6), 699-713.

46. Spencer-Oatey, H., Dauber, D., Jing, J., \& Lifei, W. (2017). Chinese students' social integration into the university community: hearing the students' voices. Higher Education, 74(5), 739-756.

47. Sullivan, C., \& Kashubeck-West, S. (2015). The interplay of international students' acculturative stress, social 
support, and acculturation modes. Journal of International Students, 5(1), 1-11.

48. Szabo, A., Ward, C., \& Jose, P. E. (2016). Uprooting stress, coping, and anxiety: A longitudinal study of international students. International Journal of Stress Management, 23(2), 190.

49. THE MINISTRY OF EDUCATION, C. (n.d.). Brief report on Chinese overseas students and international students $\begin{array}{llllll}\text { in } \quad \text { China } 2017 . & \text { Retrieved } & \text { from }\end{array}$ http://en.moe.gov.cn/documents/reports/201901/t20190115_367019.html

50. Tom, R. F. (2015). Adjustment experiences and coping strategies of first-year students at the University of Limpopo (Turfloop Campus). University of Limpopo.

51. Trice, A. G. (2003). Faculty perceptions of graduate international students: The benefits and challenges. Journal of Studies in International Education, 7(4), 379-403.

52. Verschuur, M. J., Eurelings-Bontekoe, E. H. M., \& Spinhoven, P. (2004). Associations among homesickness, anger, anxiety, and depression. Psychological Reports, 94(3_suppl), 1155-1170.

53. Wang, I. K.-H. (2018). Long-Term Chinese Students' Transitional Experiences in UK Higher Education: A Particular Focus on Their Academic Adjustment. International Journal of Teaching and Learning in Higher Education, 30(1), 12-25.

54. Witkowska, E., Witkowski, B., \& Goczek, L. (2018). Education Expenditures, Psychosocial Factors and School Performance: Evidence form Evidence from 2015 Programme for International Student Assessment.

55. World Health Organization. (2017). Depression. Retrieved July 11, 2018, from http://www.who.int/topics/depression/en/

56. Yorke, M., \& Longden, B. (2008). The first-year experience of higher education in the UK. York: Higher Education Academy.

57. Zandara, M., Garcia-Lluch, M., Pulopulos, M. M., Hidalgo, V., Villada, C., \& Salvador, A. (2016). Acute stress and working memory: The role of sex and cognitive stress appraisal. Physiology \& Behavior, 164, 336-344.

58. Zeller, W. J., \& Mosier, R. (1993). Culture shock and the first-year experience. Journal of College and University Student Housing, 23(2), 19-23. 